\title{
Mechanisms for development in corporate citizenship: a multi-level review
}

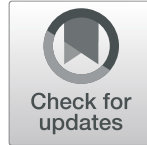

Fredrick Onyango Ogola ${ }^{1,2^{*}}$ and Josep F. Mària ${ }^{2}$

\begin{abstract}
Social Responsibility, referred to in this study as Corporate Citizenship (CC) has experienced continued growth in significance among academics and corporate leaders. The absence of a multi-level approach to what would explain the advancement in CC has inhibited a realization of singularly conclusive study. In fact, nearly every scholar in the field of CC has come up with their perspective to explain the mechanisms for development in corporate citizenship, none of them being singularly conclusive. This study takes multi-level review of the current body of knowledge on mechanisms for development in corporate citizenship. This is achieved through a comprehensive synthesis of the literature around the mechanisms for development in CC from a multi-level perspective. The findings show that the majority of scholars still populate disciplinary, specialized micro- (Managerial values), meso(Business Case) or macro- (Institutional Mechanisms) as a driver for the development of CC. we also found out that previous studies that have explored to explain drivers for CC either falls under the Managerial values, business case, or Institutional mechanisms. The findings also indicate that none of the singular perspectives have explained development in CC with conclusive results. Further the study demonstrates that it is the interaction between the different three levels of mechanisms for CC development (BC, MVs and IMs), but not acting separately is what could be driving CC to another level. Finally this study, recommends a multi-level approach to the study in social responsibility.
\end{abstract}

Keywords: Corporate social responsibility, Corporate citizenship, Drivers for corporate citizenship, Business case, Managerial values, Institutional mechanisms, Multilevel perspectives

\footnotetext{
* Correspondence: Fredrickonyongo.ogola@esade.edu;

fogola@strathmore.edu

1 Strathmore Business School, Nairobi, Kenya

2ESADE Business School, Av. De la Torre Blanca, 59, E-08172 Sant Cugat del

Valles, Barcelona, Spain
}

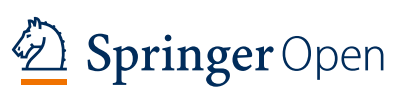

(c) The Author(s). 2020 Open Access This article is licensed under a Creative Commons Attribution 4.0 International License which permits use, sharing, adaptation, distribution and reproduction in any medium or format, as long as you give appropriate credit to the original author(s) and the source, provide a link to the Creative Commons licence, and indicate if changes were made. The images or other third party material in this article are included in the article's Creative Commons licence, unless indicated otherwise in a credit line to the material. If material is not included in the article's Creative Commons licence and your intended use is not permitted by statutory regulation or exceeds the permitted use, you will need to obtain permission directly from the copyright holder. To view a copy of this licence, visit http://creativecommons.org/licenses/by/4.0/. 


\section{Introduction}

Corporate Citizenship (CC), like many terms in management, is yet to receive a widely acceptable definition. In fact, according to Marrewijk (2003, p. 95), it is a brilliant term that "means something, but not always the same thing to everybody". Since management is, as Cuddy, Fiske, and Glick (2007, p. 1307) point out, a "low consensus" discipline; we do not pretend to define what CC is as there is not yet one commonly agreed definition.

Nevertheless, in defining CC for the purpose of this study a tradition in the literature is followed (Davis-1973ForAnd Against.pdf, n.d.; Carroll, 1979; Mcguire, Sundgren, \& Schneeweis, 1988; Mcwilliams, Siegel, \& Wright, 2006) that identifies CC as being observed situations in which the firm intentionally goes beyond compliance with the requirements of the law in pursuit of some social or environmental good. ${ }^{1}$

In recent years, $\mathrm{CC}$ has continued to grow in importance and significance. It has been the subject of considerable debate and commentary among academics, corporate leaders, and public institutions like NGOs and governments across a range of disciplines (Carroll \& Shabana, 2010). Faced with the question as what are the triggers, drivers or mechanisms behind this continued growth in significance, different authors offer different explanations, for instance, due to strategic interests of the firm, also referred to as the business case (from now, BC) (Carroll \& Shabana, 2017; Ogola, 2012), individuals' personal management values (from now, MVs), or institutional mechanisms (from now, IMs) (Campbell, 2007). The fact that there are varied explanations regarding the mechanisms for development in CC, there has emerged a confusion as which perspective or level actually explains the development in CC. Could it be partly because a panoramic view of the $\mathrm{CC}$ literature uncovers a proliferation of approaches, perspectives and views, which are complex, controversial and unclear? This is given the fact that nearly every scholar in the field of CC has come up with his perspective to explain the mechanisms for development in corporate citizenship, none of them being singularly conclusive where (1) some believe that its due to regulatory environment (2) personal initiatives of some corporate leaders, (3) Business case for CC, (4) stakeholder push, (5) industry associations demands, (6) global trends, among others. In fact within the scholars

\footnotetext{
${ }^{1}$ Corporate Citizenship (CC) has been used to "connect business activity to broader social accountability and service for mutual benefits" (Waddell 2000, P. 108). However, according to Valor (2005), newcomers in the field of business and social issues would be bewildered by a number of different terms and definitions that imply similar or identical meaning such as Corporate Social Responsibility (CSR), Business Ethics, Corporate Citizenship (CC) among other terms (p.191). In that regard, the current study uses the terms CC in a way other authors could refer to CSR.
}

who look at it at the level of business trying to prove if there is a correlation between Corporate Financial Performance and Corporate Social Performance have yielded inconclusive results. In that regard, it is still unclear how development in $\mathrm{CC}$ would be explained from a multi-level approach rather than singe level since Organizations are multilevel social systems (Hedberg, Bystrom, \& Starbuck, 1976). The current study takes multi-level review of the current body of knowledge on mechanisms for development in corporate citizenship.

We understand "development in CC" as the stage-bystage growth in terms of significance, corporate knowledge, attitudes, structures and practices that represent different levels of understanding and of sophistication about CC. In that regard, we postulate that there are three multi-level mechanisms for development in CC. On the micro- level there is Managerial Values (MVs), Meso- level business case (BC) for CC, and Macro-level institutional mechanisms (IMs. Consequently, the study contends that it is the interaction between the three levels of mechanisms that can has sufficient explanatory power with regard to why business community and organizations accept and advance the CC 'cause' hence the multi-level approach to understanding development in CC. This is analogous to the psychological Components of humans that operate at three levels yet it is their interaction that makes the human personality. There is the ID, which is the primitive, illogical, irrational, fantasy oriented, self-fish, wishful, chaotic, unreasonable, pleasure driven and pain avoidance principle. The second level is the EGO, which is the reason, reality principle that is rational, realistic, problem solving with selfcontrol that has realistic strategy to obtain pleasure. The Third level is SUPER-EGO which brings to the personality the values and morals of society hence it controls ID's impulses. Just like the multi-level interaction between MVs, BC and IMs explains the organizations CC behavior, it's the interaction between the ID, EGO and SUPEREGO that explains human behavior.

The underlying problem with the varied studies is not acknowledging that some scholars still populate disciplinary, specialized micro- (social psychology, organizational behavior, and organizational psychology), meso- (business process management and project management) or macro(strategic management, organizational theory and design, and engineering/systems management) research camps (Hitt, Beamish, Jackson, \& Mathieu, 2007; Molloy, Ployhart, \& Wright, 2011). This has led to confusion in the choice of perspective to explain the mechanism for development in CC. This apparent confusion would be solved by synthesizing the literature around one of the most important roles of management science, namely, its contribution to better management practices. To that end, the current study aims to add a perspective to the 
synthesis of CC literature by integrating it around the mechanisms for development in CC from a multi-level perspective.

Fortunately, we are witnessing an ever-increasing amount of multilevel research in organizational studies (Cohen, Burton, \& Lounsbury, 2016; Felin, Foss, \& Ployhart, 2015; Molloy et al., 2011; Paruchuri, PerrySmith, Chattopadhyay, \& Shaw, 2018; Peccei \& Van De Voorde, 2019) that integrates delineated research domains and offers new lenses for understanding management practice.

Due to the varied explanations, there is a need to provide a review of all the mechanisms for development in $\mathrm{CC}$ and how they are related in order to provide, analogy accepted here, "one-stop-shop" for mechanisms for development in CC. In fact, analogous to a supermarket where most of the household items can be found under one roof, ("one stop shop"), the different explanations for the development in $\mathrm{CC}$ (BC, MVs and IMs) are like specialized shops that we gather under one only roof.

Synthesizing CC literature is a worthy venture since the CC field projects not only a landscape of theories, but also a proliferation of approaches, perspectives and views, which are purportedly controversial, complex and unclear (Garriga \& Melé, 2013). As the current literature in $\mathrm{CC}$ is so fractured and lacking in coherence even as the volume of papers on the subject grows and the field makes progress, there is a need for a more comprehensive review paper that presents the mechanisms behind this development. Visser (2005) edged closer when he identified three catalysts for development in CC; but his work is focused only in South Africa since 2003, while the current study aims at reviews the entire CC body of knowledge. It is on this platform that the current review paper attempts to add a perspective to synthesize CC literature by integrating it around the mechanisms for development in CC.

In order to integrate the $\mathrm{CC}$ literature, the study postulates that there are three mechanisms that have led to $\mathrm{CC}$ progress in practice; business case $(\mathrm{BC})$ for $\mathrm{CC}$, institutional mechanisms (IMs) and managerial values (MVs).

The structure of this article is as follows. First, it presents the previous attempts to integrate the CC field. The study then defines the term 'mechanism' and the idea of "development"; and presents the three mechanisms for development in CC. Later on the interaction between them is argued. This is followed by a discussion on the findings of the study based on the postulation that there are three mechanisms for development in CC; business case $(\mathrm{BC})$ for $\mathrm{CC}$, institutional mechanisms (IMs), and managerial values (MVs): three mechanisms that interact with each other. Finally, the limitations of the paper and managerial implications are shown.

\section{Previous attempts to integrate CC field}

There have been several previous attempts to reduce the controversies and complexities in the Corporate Social Responsibility (CSR) field, which have been fruitful efforts that this study aims to advance. Frederick (1987) outlined a classification based on a conceptual transition from ethical-philosophical concept of CSR1-CSR4. In this classification Frederick (1987) formalized this distinction by differentiating, for instance, CSR1 from CSR2. According to Frederick (1987), CSR1 emphasized companies' 'assuming' a socially responsible posture, whereas CSR2 focused on the literal act of responding to or of achieving a responsible posture towards society. ${ }^{2}$ However, Fredrick failed to explain the mechanisms of transition from CSR1 to CSR2. Other classifications have been suggested based on matters related to CC, such as issues management (Wartick \& Rude, 1986; Wood, 1991). Brummer (1991) provided a CC classification, which displayed four categories of theories based on six criteria (motive, relation to profits, group affected by decisions, type of act, and type of effect and expressed or ideal interest). According to Garriga and Mele (2013) these classifications, in spite of their valuable contributions, are limited in scope and, moreover, fail to specify the nature of the relationship between business and society in their discussions, which is crucial since CC seems to be a consequence of how this relationship is understood (Garriga \& Mele 2013). Garriga and Mele (2013) addressed this deficiency by mapping the territory in which most relevant $\mathrm{CC}$ theories and related approaches are situated. The findings of this study stated that the most relevant CC theories and related approaches are focused either on economics, political, social interactions, or ethics, which are all aspects of social reality. This led to mapping CC theories into instrumental, political, integrative or ethical theories (Garriga \& Mele 2013, p. 51).

Among the most recent and relevant $\mathrm{CC}$ literature reviews are (Carroll \& Shabana, 2010; Lee, 2008). Lee (2008) traced the conceptual evolutionary path of theories on CC and the implications of this development. The retrospection revealed that the trend has been a progressive rationalization of the concept with a particular focus on tighter coupling with organizations' financial goals. Based on this retrospection, the limitations of the current state of CC research that places excessive emphasis on the business case for $\mathrm{CC}$ were outlined, and it

\footnotetext{
${ }^{2}$ Frederick $(1987,1998)$ out-lined a classification based on a conceptual transition from the ethical-philosophical concept of CSR (what he calls CSR1), to the action-oriented managerial concept of social responsiveness (CSR2). He then included a normative element based on ethics and values (CSR3) and finally he introduced the cosmos as the basic normative reference for social issues in management and considered the role of science and religion in these issues (CSR4).
} 
is suggested that future research needs to refocus on basic research in order to develop conceptual tools and theoretical mechanisms that explain changing organizational behavior from a broader societal perspective. However, this review fell short of clarifying the mechanism of the progressive rationalization and coupling of the CC perspectives.

Carroll and Shabana (2010) presented an extensive review of the $\mathrm{BC}$ for $\mathrm{CC}$. The authors offered the background and historical perspectives of $\mathrm{CC}$, the arguments for and against $\mathrm{CC}$, what the $\mathrm{BC}$ for $\mathrm{CC}$ really means, differentiating between the broad and narrow view of $\mathrm{BC}$ for $\mathrm{CC}$ and evidence of the $\mathrm{BC}$ for $\mathrm{CC}$. In the evidence of the BC for CSR, Carroll and Shabana (2010) came across some of the limitation of the $\mathrm{BC}$ for $\mathrm{CC}$, which reveal the complex relationship between $\mathrm{CC}$ and a firm's financial performance. Carroll and Shabana (2010) acknowledge that recognizing this complexity translates into a clear understanding of the impact of CC initiatives on Corporate Financial Peformance (CFP) while accounting for the effects of mediating variables and situational contingencies. But there is an assumption here that the $\mathrm{BC}$ demonstrated the correlation between CC and CFP as the sole relationship which fails to recognize that there can be other variables that relates to CC and CFP which do not fall within the ambit of the $\mathrm{BC}$.

Rani and Hooda (2013) and Srivastava, Srivastava, and Raibareli (2017) highlighted the importance of integrating CC literature with the role of business to in society to include business ethics, community engagement, global warming, water management, management of the use of natural resources, human rights among other issue management. Bahman, Kamran, and Mostafa (2014) reviewed the literature from the perspective of how empirical work in the field have focused on Return on Assets, Return on Equity, return on sales, Tobins Q, and stock market. Eventually, the latest review in the field presented a distinctive historical perspective on the evolution of $\mathrm{CC}$ as a conceptual paradigm by reviewing the most relevant factors that have shaped its understanding and definition, such as academic contributions, international policies and significant social and political events (Latapí Agudelo, Jóhannsdóttir, \& Davídsdóttir, 2019). The findings show that the understanding of corporate responsibility has evolved from being limited to the generation of profit to include a broader set of responsibilities to the latest belief that the main responsibility of companies should be the generation of shared value. The findings further indicate that as social expectations of corporate behavior changed, so did the concept of Corporate Social Responsibility. Moreover, findings suggest that CSR continues to be relevant within the academic literature and can be expected to remain part of the business vocabulary at least in the short term and as a result, the authors present a plausible future for CSR that takes into consideration its historical evolution (Latapí Agudelo et al., 2019).

We can conclude that previous literature, as already illustrated; provide valuable contribution to $\mathrm{CC}$ field in terms of documenting development in CC. However, some studies (Frederick, 1987) failed to explain any mechanism behind the development in CC. Other studies did explain but not in a comprehensive manner, the mechanisms behind the development in CC. These studies tend to either use the Macro-level approach (Campbell, 2007; Latapí Agudelo et al., 2019; Rani \& Hooda, 2013; Srivastava et al., 2017) or Messo level (Carroll \& Shabana, 2017; Lee, 2008; Mària \& Onyango Ogola, 2012; Nyuur, Ofori, \& Debrah, 2014; Ogola \& Dreer, 2012; Valor, 2005, 2008; Weber, 2008) while others use the micro level approach (Hemingway \& Maclagan, 2004). In that regard, CSR field is deficient of a Multi-level approach to understanding the evolution and mechanisms for the development of CC.

As a consequence of that, the study aims to contribute to Integrating organizational research body of knowledge on CC from a multi-level perspective. This is predicated on the understanding that Organizations are multilevel social systems (Hedberg et al., 1976; Kesler \& Kates, 2015) hence its behavior can only be understood at several levels that interact to produce the management practice we observe. This will be achieved by synthesizing the $\mathrm{CC}$ literature and integrate the different levels used to explain the development in $\mathrm{CC}$ whereby the majority of scholars still populate disciplinary, specialized micro- (social psychology, organizational behavior, and organizational psychology), meso- (business process management and project management) or macro- (strategic management, organizational theory and design, and engineering/systems management) research camps (Hitt et al., 2007; Molloy et al., 2011). This review of the literature will test the key assumption of multilevel organizational research that various phenomena can be better explained by combining factors at different levels of analysis (Klein \& Kozlowski, 1995) so as to make substantive progress in our understanding of the multilevel nature of organizations.

This is achieved by postulating that there are three main levels of mechanisms for development in $\mathrm{CC}$ and any other explanation for development in $\mathrm{CC}$ will fall under any of the three groups of the proposed mechanisms or the interaction between them. In addition, the study illustrates through contingency theory and the different dimensions of $\mathrm{CC}$ that there exists an interaction between these three levels of mechanisms for development in CC. 
In the section that follows, the term "mechanism" is clarified.

\section{The term "mechanism"}

In management science the term 'mechanism' has been used as an explanation between antecedents $(\mathrm{X})$ and consequences (Y). According to Gerring (2010), in recent years the importance of mechanism-centered explanation and analysis has become an article of faith within management sciences. This is because the turn towards mechanisms unites researchers practicing a wide array of methodologies, approaches, perspectives and views.

The term 'mechanism' has several meanings but in the context of this study it means the pathway or process by which an effect is produced, which is also a contextdependent explanation. This is the understanding the current study takes when it synthesizes the mechanisms (X) for development in CC (Y) by considering the contingency perspective (Gerring, 2010). Contingency perspective would consider that there could be $\mathrm{BC}$ for CC (a positive relationship between Corporate social Performance (CSP) and CFP) but at the same time other variables that moderate this relationship. In that regard, the current study looks at broader pathways or processes by which $\mathrm{CC}$ has developed. This broad pathway considers not only $\mathrm{BC}$ as a mechanism for development in CC but also MVs and IMs. Turning to this mechanistic explanation for development in CC unites researchers who have taken different approaches (BC, MVs or IMs) with regard to examining one of the basic questions in CC: why has CC continued to grow in importance and significance among academics and business communities?

\section{The idea of "development in CC"}

The second term to be clarified is "CC development". It is the stage-by-stage growth in significance, corporate knowledge, attitudes, structures and practices that represent different degrees of understanding and of sophistication (Mirvis \& Googins, 2007). In that regard, mechanisms for development in CC are understood as the rationale, forces or drivers behind the continued advancement in the practice of $\mathrm{CC} .^{3}$

\footnotetext{
${ }^{3}$ Some of the mechanisms can turn into mechanisms of regress, for instance, Suchman (1995 P. 601) holds the view that institutional pressures can lead to regress in CC development\}. The study has consciously chosen this approach in order to give arguments to those who wish to contribute to the development in CC. Another reason why we choose to concentrate in the mechanisms for development in $\mathrm{CC}$ rather than regress is because in as much as it's important for the literature of management science to highlight the dark side of management practice; its essential role seems to be its contribution to better management practices.
}

\section{Mechanisms for development in CC}

In order to fully explain any causal relationship, one must state how the antecedents lead to the consequences and in what contexts, and as well, argue against alternative explanations (Gerring, 2010). Certainly, there has been development in CC but the cause of this development has not been systematically documented in the CC literature from the multi-level approach. Mirvis and Googins (2007), for instance, present stages of development in CC. According to them, there are a number of models of "stages" of CC, namely; elementary stage followed by engaged, innovative, integrated and lastly transforming stage. This raises the question as to what are the explanatory mechanisms for the transition from one stage of CC to another, development in CC? In fact these authors acknowledge that the generative logic and mechanisms that drive the development in $\mathrm{CC}$ within organizations have not been addressed. In that regard, these authors adopt Greiner's model of revolution as organizations grow (Greiner, 1998).

Effectively, in Greiner's terms, the development of an organization is punctuated by a series of predictable crises that trigger responses that move the organization forward. The triggering mechanisms here are tensions between current practices and the problems they produce that demand a new response from a firm. In development language, according to Greiner, companies "master" these challenges by devising progressively more effective and elaborate responses to them. The triggers or drivers for movement are challenges that call for a fresh response. Interpreting Greiner, Mirvis and Googins assume that Greiner's model is normative in that it posits a series of stages in the development of CC. For Mirvis and Googins, the challenges for $\mathrm{CC}$ development center initially on a firm's credibility as a corporate citizen, then its capacity to meet expectations, the coherence of its many subsequent efforts, and, finally, its commitment to institutionalize citizenship in its business strategies and culture. However, these authors find themselves on a dilemma since movement along a single development path is not fixed nor is attaining a penultimate "end state" a logical conclusion. The authors then state that the arc of citizenship within any particular firm is shaped by socio-economic, environmental, and institutional forces impinging on the enterprise as proposed by Vogel (1992): an author who finds considerable variability in the business case for citizenship across firms and industries and thus limits to its market place reward. Therefore, Mirvis and Googins conclude, notwithstanding, that a company's response to these market forces also varies based on the attitudes and outlooks of its leaders, the design and management of its citizenship agenda, and firm specific learning. One of the limitations of Mirvis and Googins explanations of the drivers, 
triggers or mechanisms for development in $\mathrm{CC}$ is that instead of being descriptive on the mechanisms for development in $\mathrm{CC}$ they take the normative trajectory. In that regard, in as much as there are some explanations, they are not comprehensive since they tend to explain in parts without systematically considering other factors. That is why the current study contends that the increased acceptance and incorporation of CC into doing business can be attributed drivers from several levels (Macro-Messo-micro). The current paper, therefore, seeks to identify the different mechanisms before classifying them in the light of the first postulation of the study; that all explanations for development in CC can be categorized into three mechanisms, BC (Micro), MVs (Messo) and IMs (maro) based on Wood's model of CSP. In that regard, we first present Wood's model to justify our categorization into the three mechanisms.

\section{Rationale for the categorization of mechanisms for development in CC}

The rationale for the categorization of mechanisms of $\mathrm{CC}$ development into three categories (levels), and their interaction comes from Wood's approach to CSP (Wood, 1991).

In fact, Wood (1991 p. 693) defines CSP as a business organization's configuration of principles of social responsibility, processes of social responsiveness, and policies, and observable outcomes as they relate to the firm's societal relationships. Wood (1991) constructed the CSP model as outlined in Table 1.

From Table 1, our study only concentrates on the three principles of $\mathrm{CC}$, which the study used as the basis of the triad (BC, IMs, and MVs). The institutional principle, which the study uses to seek legitimacy, is associated with the IMs for development in CC; the organizational principle, which relates to public responsibility of corporation relates to the $\mathrm{BC}$; and finally the individual principle, which is social responsibility of the

Table 1 Wood's Model of CSP. Source: Wood (1991, p. 694)

Principles of CSR
- Institutional principle: legitimacy
- $\quad$ Organizational principle: public responsibility
Processes of Corporate Social Responsiveness
- $\quad$ Environmental assessment
- Stakeholder management
- Issues management
Outcomes of Corporate Social Behavior
- Social policies
- Social programs
- Social impacts

firm at managerial discretion, relates to MVs as a mechanism for development in CC. This justifies why we have chosen three mechanisms (levels) but not, for instance, two or four mechanisms. This is confirmed by identifying mechanisms for development in $\mathrm{CC}$ in the current literature.

Upon designating and justifying the three mechanisms which we use Woods model of CC as our foundation, we now need to come up with a comprehensive list of mechanisms for development in CC then classify them into the three mechanisms. In that regard, to identify the comprehensive list of mechanisms for development in CC, the study carried out a Google search using Google scholar as the search Engine. The terms "mechanisms for CSR progress" and "Drivers for CSR progress" was searched in Google scholar. 242 articles appeared. The following list represents the non-repetitive titles of the main articles that appeared:

- Managers' Personal Values

- Goal of Multilateral development in CSR

- Government as a driver for CSR

- CSR education in Europe

- Drivers of Environmental behavior

- Investment funds (institutional investors) as a driver for CSR

- Public Sector role in Strengthening CSR

- The Business Case for CSR

These articles were then content analyzed with an aim of drawing from them anything referred to as mechanisms or drivers for development in CC. Backward and forward citations of the articles were also done to gather other mechanisms or drivers from related articles. This process was carried out to saturation, until the next articles added nothing new as a driver for development in CC. The study also came across a group of actors and drivers presented in the Oxford handbook of CSR edited by Crane, McWilliams, Matten, Moon and Siegel (2008; Matten \& Moon, 2004; Moon, 2004; 2008 p. 227-303). They include:

- Top managers as drivers for CSR

- Socially responsible investment and shareholder activism

- Consumers as drivers of CSR

- CSR, Government, and Society

The study classified the drivers or mechanisms that emerged from the pool as the main explanations, drivers or mechanisms for development in CC into three as the study had postulated. These are Business Case (BC) for CSR, Managerial Values (MVs) and Institutional Mechanisms (IMs) for CSR progress. We now proceed to 
explain the three groups of mechanisms gathered from the literature that was searched above.

\section{Business case as a mechanism for development in CC}

The business case for $\mathrm{CC}$ refers to the underlying arguments or rationale supporting or documenting why the business community should accept and advance the CC 'cause'. The business case is concerned with the primary question: what do the business community and organizations get out of CC? For most, the business case refers to the bottom-line reasons for pursuing CC strategies and policies (Carroll \& Shabana, 2010). A business case argument, therefore contend that firms which engage in $\mathrm{CC}$ activities will be rewarded in the market in economic and financial terms.

It is worth noting at this point that $\mathrm{BC}$ for $\mathrm{CC}$ dominates the CC literature in terms of explaining the mechanisms for development in CC without necessarily having greatest explanatory power. This is illustrated by the fact that empirical research aimed at proving that there is a positive relationship between Corporate Social Performance (CSP) and Corporate Financial Performance (CFP) has had inconclusive results. Inconclusive results are evident in the inconsistencies in the results of previous empirical studies investigating the CSP-CFP relationship (Roman, Hayibor, \& Agle, 1999). One category shows a positive link between CSP and CFP, the second shows a negative link, and the third shows no link. It is important to clarify here that (Baron, 2010; Baron \& Kenny, 1986) distinguishes between CSP and $\mathrm{CC}$, where the latter involves a moral duty to undertake social activities. In contrast, CSP need not arise from moral responsibilities. CC implies CSP, but CSP need not be morally motivated, since CSP could be strategically chosen to serve the interests of the firm.

In making a business case for $\mathrm{CC}$, there has been both theoretical and empirical research. According to Carroll and Shabana (2010) Questions such as the following have framed this research: Can a firm really do well by being good? What are the bottom-line benefits of socially responsible corporate performance? Is there a positive CSP-CFP relationship? These have seen researchers venture in investigating the relation between CC and CFP (Argenti, 2004; Bahman et al., 2014; Margolis \& Walsh, 2003; Steger, 2006; Wagner, NguyenVan, Azomahou, \& Wehrmeyer, 2002; Wagner \& Schaltegger, 2004; MSteger 2001), business benefits from CC (Gray \& Balmer, 1998; Schwaiger, 2004; Steger, 2006; Thorpe \& Prakash-Mani, 2003; Wiedmann \& Buxel, 2005), investment and stakeholder evaluation (Dixit \& Pindyck 2004; Figge \& Schaltegger 2000; Rappaport 1998), CC impact assessment (Burke \& Logsdon, 1996; Kaplan \& Norton, 2006), assessment of monetary
CC Value-Added (Brealey, Myers, \& Allen, 2006; Epstein \& Roy, 2001; Muller, Judd, \& Yzerbyt, 2006; Murphy et al., 2005; Schaltegger 1998; Schaltegger \& Müller, 2017; Steger, 2006), CC and costs (Hartman, Hofman, \& Stafford, 2002), and CC risks (Argenti, 2004; Brealey et al., 2006; Schaltegger \& Müller, 2017).

The aftermath of this has seen various management disciplines such as quality management, marketing, communication, finance, Human Resource Management, and reporting recognize that $\mathrm{CC}$ fit their business purposes as well (Lee, 2008).

The effect of the business case on corporate managers, shareholders among other stakeholders makes the $\mathrm{BC}$ a mechanism for development in CC. There is no doubt the $\mathrm{BC}$ for $\mathrm{CC}$ has made some corporate managers rethink CC (Vogel, 1992). Most scholars point to Howard Bowen's Social Responsibilities of the Businessman (Bowen et al., 2013; Preston, 1975) as the first attempt to theorize the relationship between corporations and society (Carroll, 1979; Preston, 1975; Wartick \& Rude, 1986). In fact, Bowen's book provided the intellectual springboard to reflect on the rapidly changing social environment during the ensuing two decades (Lee, 2008).

The other aspect of the BC, which came in 1970s, is what Lee (2008) refers to as Enlightened Self-Interest. The authors in this period in time recognized that without demonstrating that $\mathrm{CC}$ is consistent with stockholder interests, CC will always remain anti-business hence incompatible with business (Ackerman, 1973). The modern corporate equity holding patterns became so diversified that the meaning of stockholder interest has also been significantly altered enabling the business community and investors embrace CC. The BC for CC transformed the shareholders' perspectives, which led to development in CC. This is because the meaning and business implications of CC nowadays is much more palatable to shareholders than the one advocated in the times of Howard Bowen.

Around 1919, for instance, the concept of CC was vaguely framed in moral and macro-social terms such that the shareholders could not see how it served their interest or how it was related to the performance and management of the corporation. Since there was no established logical linkage between CC and CFP and that most shareholders invest in a company not to make a difference in society but to gain a sizeable financial return on investment (Lee, 2008), shareholders could not see the need for their money being spent on $\mathrm{CC}$, not until the $\mathrm{BC}$ made some breakthrough. In that regard, the study echoes the already discussed proposition that the $\mathrm{BC}$ for $\mathrm{CC}$ has led to the development in $\mathrm{CC}$. $\mathrm{BC}$ for $\mathrm{CC}$ is taken basically in terms of CSP-CFP relationship which is used in building the model that considers 
simultaneously other drivers for development in $\mathrm{CC}$ as shown in Fig. 1.

\section{Managerial values as a mechanism for development in CC}

Research has shown that the commercial imperative- $\mathrm{BC}$ for $\mathrm{CC}$ in this case - is not the sole driver of CC decision-making but that the formal adoption and implementation of $\mathrm{CC}$ by firms could also be associated with socially conscious values of organizational managers (Hemingway \& Maclagan, 2004). In some of the limitations of the BC, Carroll and Shabana (2010) realized that there is complex relationship between CSP and CFP. Recognizing this complexity translates into a clear understanding of the impact of $\mathrm{CC}$ initiatives on financial performance while accounting for the effects of mediating variables and situational contingencies like the managerial values of corporate leaders. In fact, while the firm is the focal point for social responsibility initiatives, constituting as it does the immediate environment in which resource allotment decisions take place, it is of course the people acting individually or in groups who operationalize social responsibility through their decisions and actions (Haigh \& Jones, 2006). That is why we include MVs in the conceptual framework, Fig. 1.

Surprisingly the idea that top managers can be drivers for CC came from the business sector itself. This is contrary to the popularly held myth in some circles that CC advocates and business representatives are in opposing camps. The contribution of MVs as driver for CC can be traced to the 1950s when corporate leaders in the United States, followed by academics at pedigree universities, called for business to act as trustee of social well-being (Crane et al., 2008).

Since then scholars in the fields of institutional analysis, comparative political economy, and corporate governance have demonstrated through their research findings that the cognitive frames, mindsets, conceptions of control, or worldviews of corporate managers are important determinants of how managers run their firms (Aguilera \& Jackson, 2003; Dore, 2017; Hall \& Sosckie, 2001; Whitley, 2004). Scholars emphasize that managers often learn these mental constructs by absorbing the messages that are transmitted to them at business schools and through the professional publications they pay close attention to (for instance, the business press, trade journals) (Campbell, 2007). Academy, T, and Review, M (2017), for instance, demonstrated that corporate executives' approach to managing their firms depended in part on the sorts of training they received in business schools. Guillen (1994) showed that managerial views on which business models were acceptable or not were related in part to the models that received the most attention in the academic and business press (Campbell, 2007).

In fact, recognizing the influence of managerial value systems in development in CC is probably one of the reasons why publications like the Harvard Business Review have been running articles advocating socially responsible corporate behavior (Harvard 2003) and why business schools in Europe and the United States have incorporated courses on business ethics into their curriculum (Matten \& Moon, 2004; Vogel, 1992).

For instance, Minnesota Project on Corporate Social Responsibility (MPCSR) was created to educate managers on CC. MPCSR offered a core curriculum for executives that focused on the fundamentals of CC, public-private partnerships and international business responsibilities among others (Campbell, 2007). Moreover, Galaskiewwicz (1991) found that managers from local firms that had participated in MPCSR tended to embrace an ethic of enlightened self-interest and social responsibility. Therefore, in as much as the $\mathrm{BC}$ for $\mathrm{CC}$ is essential, academic formation of the managers in business schools to ensure the entrenchment of social responsibility in managers is also valuable. In that regard, MVs affects CSP and CSP can also affect MVs. Likewise, MVs can also impact on CFP as MVs can be informed

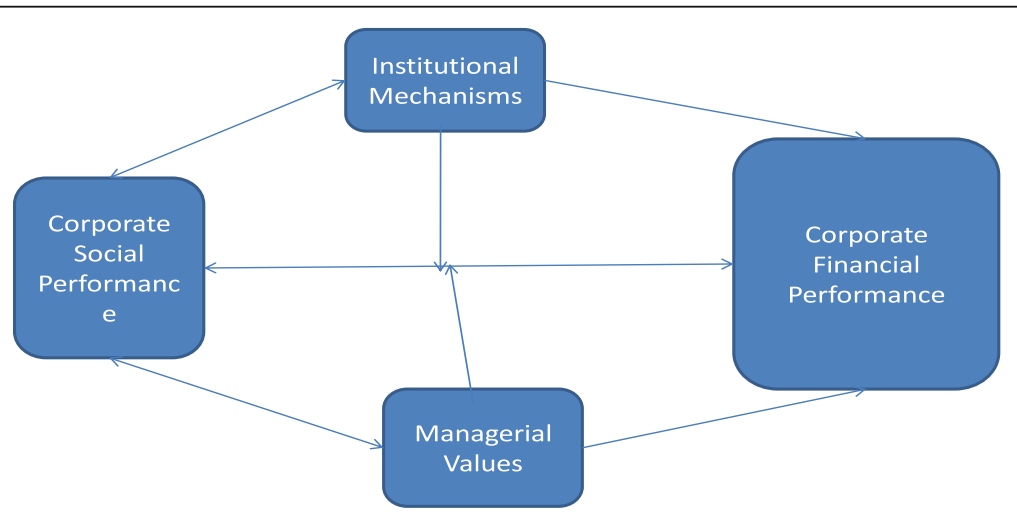

Fig. 1 Framework for mechanisms 4 CSR progress. Source: Author's own elaboration 
by CSP, which is defined by this study to mean CC only that there is the perspective of how firms can use their social responsibility initiatives for its own interest, bottom-line. That is why we suggest a correlation between CSP and MVs, (Fig. 1).

Managerial values could also be essential in the journey from strategic intent to strategy implementation. According to Hitt, Tyler, Hardee, and Park (1995) strategic intent is a high-level statement of the means by which an organization achieves its vision. Simply put, a strategic intent is a company's vision of what it wants to achieve in the long term. Strategy implementation is the translation of chosen strategy into organizational action so as to achieve strategic goals and objectives (Brodwin \& Bourgeois III, 1984).

Strategy implementation skills are not easily mastered, unfortunately. In fact, virtually all managers find implementation the most difficult aspect of their jobs - more difficult than strategic analysis or strategy formulation. U.S. managers spend more than $\$ 10$ billion annually on strategic analysis and strategy formulation. Managers themselves report that less than half the plans resulting from these efforts are ever implemented. Outside observers put the success rate even lower: less than $10 \%$. The ability to implement strategies is one of the most valuable of all managerial skills (Jablonsky, 1995). In that regard, a firm can get it right in coming up with a strategic intent that maximizes CSP-CFP relationship within the right IMs but lacks MVs to implement. That is why $\mathrm{BC}$ as a mechanism on its own is limited in its predictive power as to the reasons for development in CC.

\section{Institutional mechanisms for development in CC}

Prior to looking at the institutional mechanisms for CC, we define the term 'institution'. Institutions, by North's definition, are the basic rules of the road in an economy, including formal systems, such as constitutions, laws, taxation, insurance, and market regulations, as well as informal norms of behavior, such as habits, customs, and ideologies (North, 2004).

According to North (2004), institutions are both formal and informal. Formal institutions are rules and regulations that are devised by human beings to achieve a certain goal. Informal institutions are conventions and codes of behavior (North, 2004). Unfortunately, "We cannot see, feel, touch or even measure institutions; they are constructs of the human mind". Nevertheless institutions have power (North, 2004, p.107). In fact, institutional forces determine what organizations come into existence, remain in existence and how they evolve (North, 2004, p.5).

At the institutional level, powerful social and political forces encourage organizations to act more responsibly. Campbell (2007) proposed an institutional theory of CC in which he depicted five conditions under which a firm would behave in a socially responsible manner. These include, first, public and private regulation, second, the presence of non-governmental and other independent organizations that monitor corporate behavior, third, institutionalized norms regarding appropriate corporate behavior, fourth, associative behavior among corporations themselves, and fifth, organized dialogue among corporations and their stakeholders (Campbell, 2007). These institutional forces have played an important role in the development in CC.

Besides Campbell's institutional theory of CC, other authors have proposed different institutional parameters that have led to development in CC. These include Government as a driver for CC (Fox, Ward, \& Howard, 2002; Moon, 2004), the push by political/ ethical consumer due to growing consumer demand for responsibly made products (Haigh \& Jones, 2006; Heslin \& Ochoa, 2008; Pruzan, 2001); the ethical investor which manifests itself in the pressure from socially responsible investors through public interest proxy resolutions (Haigh \& Jones, 2006; Heslin \& Ochoa, 2008; Pruzan, 2001); attracting and retaining good employees (Pruzan, 2001); regulatory pressure especially in the new forms of accounting such as development of environmental accounting with legal demands as to the publication of such reports (Haigh \& Jones, 2006; Pruzan, 2001) which came from the Global Reporting Initiative (GRI) (Haigh \& Jones, 2006); pressure from popular mobilizations like NGOs (Haigh \& Jones, 2006); industry codes of conduct (Heslin \& Ochoa, 2008) among other institutional mechanisms.

These institutional mechanisms have also enhanced the development in $\mathrm{CC}$ as companies, which did not buy into the $\mathrm{BC}$ and/or lack the MVs for development in CC have been forced to comply. Institutional mechanisms can also provide business incentives such as tax concessions, friendly regulatory environments among others to firms that are socially responsible hence affecting CFP. The relationship between IMs and CSP can be a correlation: the more advanced the CSP, the more sophisticated the IMs become, (Fig. 1).

It is also possible that a firm can embrace CC for all the reasons stated above, that is, they can advance the CC cause due to their perceived CSP-CFP relationship and at the same time due to the fact that they have managers who are highly ethical who want to leave a good legacy and due to institutional pressures. That is why the current study postulated that there is an interaction between these groups of mechanisms for development in CC, (Fig. 1).

\section{Interaction between the three mechanisms}

According to Campbell (2007, p. 954), researchers have called for a greater attention to the factors that moderate 
the relationship between economic conditions, such as CFP and CC. While Campbell responded to this call by proposing institutional explanations of socially responsible behavior, he turned a blind eye to how economic conditions interact with institutional explanations and managerial values as well. According to Haigh and Jones (2006), influences on CC practice tend to overlap in quite complex ways yet they are analytically distinct in terms of their internal logics and immediate referents. For instance there can be an overlap between $\mathrm{BC}$ as a mechanism for development in CC, MVs and the IMs for development in CC. Contingency theory can shed some light on this.

It is critical to apply the contingency perspective as suggested by Barnett (2018) in order to account for the role of mediating variables in a model, as proposed by Pivato, Misani, and Tencati (2008) in the exploration of the CSP-CFP relationship. According to Carroll and Shabana (2010) a contingency perspective would allow the development of justifications for the lack of a positive relationship between $\mathrm{CC}$ and firm performance in certain circumstances. In fact, it would provide a defense for the $\mathrm{BC}$ for $\mathrm{CC}$ in circumstances where the $\mathrm{BC}$ is argued to have failed (De Schutter, 2008; Valor, 2005, 2008; Williamson, Lynch-Wood, \& Ramsay, 2006). This presents an opportunity for considering the contribution of other mechanisms for development in CC, MVs and IMs.

A contingency theory differs from other theories in the specific form of the propositions. The distinction between congruent and contingent propositions made by Fry and Smith (1987) clarifies this difference. In a congruent proposition a simple unconditional association is hypothesized to exist among variables in the model; for instance, in a $\mathrm{BC}$ argument the more socially responsible a firm is (CSP) the more profitable it becomes (CFP). However, a contingent proposition is more complex, because a conditional association of two or more independent variables with a dependent outcome is hypothesized and directly subjected to an empirical test; for example, there could be a positive relationship between CSP and CFP but contingent on IMs and/or MVs. This suggests that IMs and MVs mediate the CSP-CFP relationship as shown in Fig. 1.

In the light of contingency theory, using contingent propositions as opposed to congruent propositions, the current study contends that interaction between the three mechanisms (BC, MVs and IMs) already presented in this study would have more explanatory power with regard to mechanisms for development in CC than any single one of them.

In fact, the relationship between each mechanism (Predictor variable, $\mathrm{X}$ ) and the CSP (outcome variable $\mathrm{Y}$ ) is very unlikely a direct effect since there could be moderator and/or mediator effects, (Fig. 2). A predictor variable is a variable used in regression to predict another variable. It is sometimes referred to as an independent variable if it is manipulated rather than just measured. A moderator variable is a variable that alters the strength of the causal relationship. A mediator variable is a variable that describes "how" rather than "when" effects will occur, by accounting for the relationship between the independent and dependent variables. A mediating relationship is one in which the path relating $\mathrm{X}$ to $\mathrm{Y}$ is mediated by a third variable $(\mathrm{Z})$ (Baron \& Kenny, 1986; Muller et al., 2006).

Moreover, the fact that much research on the $\mathrm{BC}$ that investigated CSP-CFP relationship was inconclusive (Lee, 2008) could be explained by the fact that not all the relevant variables that could act as moderator or/and mediator variables inherent in the MVs and IMs were considered. This is the contribution that the acknowledgement of the interaction between the three models in the context of contingency theory can bring to the CC field.

The interaction between the three mechanisms for development in CC from their foundational arguments is now illustrated. This is achieved by displaying how scholars could use both MVs and IMs to make a BC for $\mathrm{CC}$ as evidence of the interaction between the three mechanisms.

In making the $\mathrm{BC}$ for CSR, as stated earlier, scholars invoke the CSP-CFP relationship. MVs and IMs can also be incorporated in this model. Siegel, Waldman, and Javidan (2006), for instance, used transformational leadership theory to explore the role of CEOs in determining the extent to which their firms engage and benefit financially from their CC. They found CEO intellectual stimulation (but not CEO charismatic leadership) to be significantly associated with the propensity of the firm to engage in 'strategic' CC (CSP), or those CC activities that are most likely to be related to the firm's corporate and business-level strategies. The findings of this study suggest that in spite of the fact that MVs have been highlighted as the driver for $\mathrm{CC}$, relationship with the $\mathrm{BC}$ for CC is also implied. This is because MVs is used in advancing $\mathrm{CC}$ causes but in such a fashion that enhances the firm's CFP. This reveals that it is unlikely that there is a direct effect between CSP and CFP but that there are moderating effects from other variables such as MVs. This echoes an interaction between MVs and BC as mechanisms for CSR progress. But do the IMs also interact with intellectual stimulation as a managerial value to produce a $\mathrm{BC}$ for CSR while delivering CSP? To realize this we need to first understand what is meant by intellectual stimulation.

Intellectual stimulation involves leader actions geared toward the arousal and change in problem awareness 


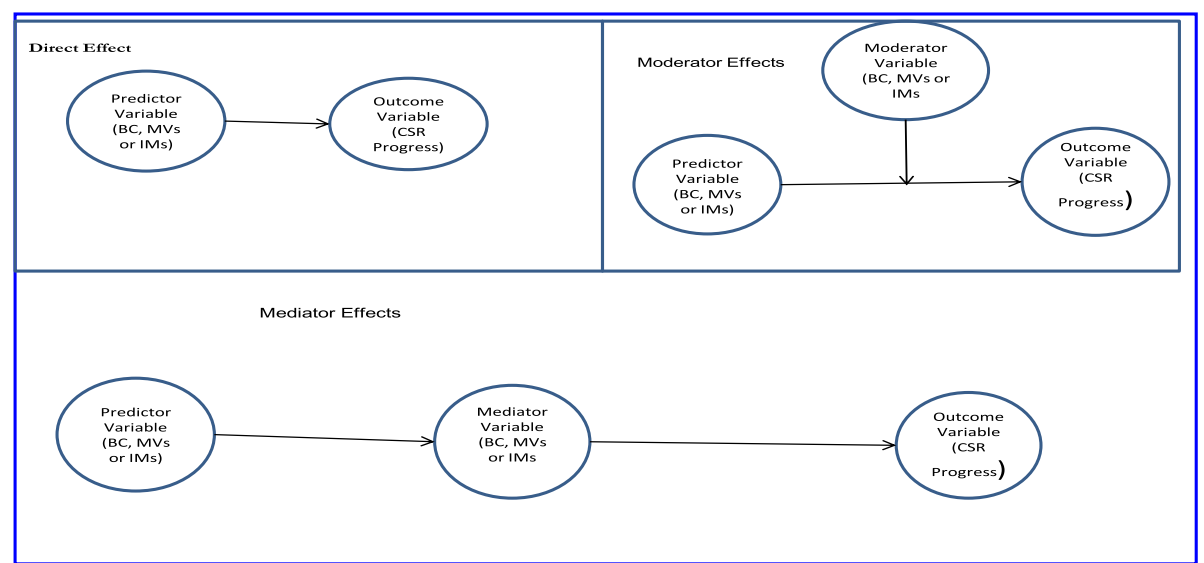

Fig. 2 Direct, Moderator and Mediator Effects between the proposed three mechanisms for CSR progress. Source: Author's elaboration

and problem solving on the part of followers, as well as beliefs and values (Kesler \& Kates, 2015). Crossman and Crossman (2011) described the importance of top-level executives engaging themselves and subordinates in the intellectual task of conceptualizing and articulating a firm's broader environmental context, as well the threats and opportunities posed by that context. These scholars stressed that conceptual capacity is more important at higher levels of management, especially in the context of strategy formulation.

Waldman (1999) stresses that intellectually stimulating leaders will use conceptual capacity to scan and think broadly about the environmental context and the manner in which a wide variety of organizational stakeholders may be served. Their mental maps include a dynamic picture of how the various external forces interact with the form and with each other and as a result, present a richer perspective of firm performance and competitive advantage that goes beyond simple cost leadership or product differentiation (Porter \& Kramer, 2006).

IMs are also incorporated in the CSP-CFP relationship moderated by MVs. This is because intellectual stimulation as MVs is capable of incorporating firm's broader environmental contexts, threats and opportunities into important strategy formulation. This strategy formulation takes into consideration different stakeholder interests, which come up with a richer strategy that executes firm performance and competitive advantage in order to enhance CFP. This illustrates how MVs interact with IMs to influence a CSP-CFP relationship. This is because some of the threats considered in the intellectual stimulation could be due to government regulation, pressure from consumers for responsibly produced products and pressure from investors through institutional investors. Opportunities could include government tax concessions for investments on CSP. In the proposed model a management must have values (intellectual stimulation) in order for them to capture the opportunities and threats in the external environment, which is mostly institutional, and relate with firms strategic goals (CFP) to deliver CSP. This illustrates the interaction between $\mathrm{BC}$, MVs and IMs as mechanisms for development in CC, (Fig. 1).

\section{Discussion}

We use the discussion section to apply CC dimensions as proposed by Smith (2011) to illustrate the interaction between the three mechanisms for development in CC. This also demonstrates how this study contributes to the implementation of some or all of the five CC dimensions simultaneously.

With regards to CC dimensions, Smith (2011) gathered a total of 37 definitions from 27 authors in an extensive review literature spanning from 1980 to 2003. The finding indicates that $\mathrm{CC}$ has five major dimensions: environmental, social, stakeholder, economic and voluntariness, (Table 2).

What is intriguing with the $\mathrm{CC}$ dimensions offered by Smith (2011) in the light of one of the postulates of this study, (that CC cannot be explained from one level but must a multi-level explanation), is conjecture that corporations seem to do different kinds of $\mathrm{CC}$ and more so for different purposes. With regard to the different $\mathrm{CC}$, some corporations can concentrate on any of the five CC dimensions (environmental, social, economic, stakeholder and voluntariness), some of them or all the five together. This depends on how the firm has developed in its $\mathrm{CC}$ practices. This is because the different types of CC serve different purposes for an organization. For instance, corporations may have to be; environmentally responsible because it is a regulatory requirement so it's 
Table 2 Five dimensions of corporate social responsibility

\begin{tabular}{|c|c|c|}
\hline Dimensions & Definition of the dimension & Phrase describing the dimension \\
\hline $\begin{array}{l}\text { A. The } \\
\text { environmental } \\
\text { dimension }\end{array}$ & 1. The natural environment & $\begin{array}{l}\text { i. A cleaner environment } \\
\text { ii. Environment stewardship } \\
\text { iii. Environmental concerns in business operations }\end{array}$ \\
\hline $\begin{array}{l}\text { B. The social } \\
\text { dimension }\end{array}$ & 2. The relationship between business and society & $\begin{array}{l}\text { i. Contribute to better society } \\
\text { ii. Integrate social concerns in their business operations } \\
\text { iii. Consider the full scope of their impact on communities }\end{array}$ \\
\hline $\begin{array}{l}\text { C. The economic } \\
\text { dimension }\end{array}$ & $\begin{array}{l}\text { 3. The socio-economic or financial aspects, including describing } \\
\text { CSR in terms of a business operation }\end{array}$ & $\begin{array}{l}\text { i. Contribute to economic development } \\
\text { ii. Preserving the profitability } \\
\text { iii. Business operations }\end{array}$ \\
\hline $\begin{array}{l}\text { D. The stakeholder } \\
\text { dimension }\end{array}$ & 4. Stakeholders or stakeholder groups & $\begin{array}{l}\text { i. Interact with their stakeholders } \\
\text { ii. How organizations interact with their employees, } \\
\text { suppliers, customers and communities } \\
\text { iii. Treating the stakeholders of the firm }\end{array}$ \\
\hline $\begin{array}{l}\text { E. The voluntariness } \\
\text { dimension }\end{array}$ & 5. Actions not prescribed by law & $\begin{array}{l}\text { i. Based on ethical values } \\
\text { ii. Beyond legal obligations } \\
\text { iii. Voluntary }\end{array}$ \\
\hline
\end{tabular}

Source: Adopted from Dahlsrud, 2008

important in securing legal license to operate due to institutional influences, socially responsible in order to get the social license to operate, economically responsible due to shareholder influence, participate in stakeholder engagement for risk management that benefits CFP, and voluntariness championed by managerial values, managers who want to live a legacy.

Social and economic dimensions can be attributed to $\mathrm{BC}$ for $\mathrm{CC}$. With regard to social dimension, firms are concerned with how they would relate to the society in such a manner that it would capture and sustain competitive advantage while the economic dimension ensures CC contributes to economic development which is beneficial to society while preserving the profitability and improving business operations which benefits the firm. This is instrumental CSR. The underlying logic is that the more management finds a formula for this shared value approach between society and business as proposed by Porter and Kramer (2006) the more likely the development in $\mathrm{CC}$ due to the $\mathrm{BC}$.

Voluntariness dimension can be attributed to MVs as a driver for CC. This is because a firm could be carrying out $\mathrm{CC}$ by going beyond what is required by law and its own self-interest in what falls under voluntary dimension of CC. This voluntary dimension can be carried out due to MVs. The voluntariness dimension falls under MVs due to the fact that they are carried out voluntarily, probably due to ethical values of managers who may wish to leave a legacy since they entail going beyond legal obligations and may not necessarily be influenced by CFP.

Stakeholder and Environmental dimensions can be attributed to IMs. This is because environmental responsibility tends to fall under government regulation. There are also several international organizations that regulate environmental responsibility like UN Global compact instituted by former UN secretary general Kofi Annan, and the Kyoto protocol, among others. Stakeholder dimension falls under IMs since it harbors, for instance, institutional investors who tend to push firms to align their operations and strategies with universally accepted principles in the areas of human rights, labor, environment, anti-corruption and sustainable development. There is also pressure from ethical consumers who are also stakeholder who push for socially responsible products. In addition, some stakeholders like governments and NGOs are regulators, which form part of the IMs. Stakeholder engagement with such stakeholders consequently leads to development in CC.

In the classification of the different CC dimensions with respect to the three main mechanisms (levels of) for development in $\mathrm{CC}$, the postulation that there exists an interaction between the three mechanisms is illustrated hence the multi-level approach to explaining the development in CC. As we said earlier, different firms carry out different types of $\mathrm{CC}$ with regard to the five dimensions and for different purposes, so it can be concluded that one firm practicing more than one type of $\mathrm{CC}$ can be driven by at least more than one mechanism for development in CC. The firm may find itself making its socially responsible behavior progress, therefore, not only due to the $\mathrm{BC}$, MVs or IMs but due to a combination of some of them, if not all. In fact, since the five components of $\mathrm{CC}$ require all the three mechanisms to be practiced by a firm operating at the three levels, a firm could find the interaction of the three mechanisms in the model helpful in its development in CC. In that regard, this study contributes to how the interaction between the mechanisms can lead to the implementation of the five $\mathrm{CC}$ dimensions, a recommendation that if followed explicitly by practitioners, there would be significant development in CC. 


\section{Final considerations}

This final section will include the conclusions and the limitations of this study.

\section{Conclusions}

The purpose of this paper has been to add a perspective to the synthesis of CC literature by integrating it around the mechanisms for development in CC. It is true that in the last years CC has developed rather than not, even if this is only a general tendency (a tendency that CC academics have enforced for different reasons - irony accepted here: "CC academics win their salary praising the glories of $\left(C^{\prime \prime}\right)$. This article wishes to explain the mechanisms of development in CC (some of which can turn into mechanisms of regress!) in order to give arguments to those who wish to contribute to the development in CC, maybe now in a less friendly context. In fact, we contend that a perspective that is at the same time intellectually well founded and teleologically focused on the betterment of societies is actually contributing to this betterment. Our sincere effort has been to humbly help in building such a perspective. The perspective built in this study has attempted to provide a multi-level approach rather than a singular level on mechanisms for development in $\mathrm{CC}$ since the previous literature had only explained the development from either Macro-, messo- or micro-level. In that regard, we contribute to CC literature in its current form by proposing taxonomy of mechanisms for development in CC from a multi-level perspective. We propose that CC has developed primarily due to the triad (BC, MVs and IMs), which produced a secondary mechanism (multi-level perspective), the interaction between them. It is interesting to note that though secondary, the multi-level understanding to the mechanisms could well be the one that has greater explanatory if not predictive power of the underlying arguments or rationale supporting or documenting why the business community has continued to accept and advance the CC 'cause'. Therefore, CC academics and practitioners wishing to advance CC 'cause' could benefit by explicitly contemplating this model in their research and $\mathrm{CC}$ practices respectively. This is because our contribution with regard to the interaction of the three main mechanisms (levels) for development in CC explains how firms navigate CC issues in a world populated by values, interests, and the institutions that collectively lead to development in CC hence the interaction mechanism holds more explanatory or predictive power than any single Driver for development in CC. This demystifies the issue of inconclusive results from studies that have only focused on the $\mathrm{BC}$ incognizant that CSP-CFP relationship could be contingent on MVs and/or IMs.
In yet another contribution, the current study's attempt at explaining development in $\mathrm{CC}$ in terms of mechanisms is an effort to unite researchers who have taken different approaches (BC, MVs or IMs) with regard to responding to the basic question in CC: why or has $\mathrm{CC}$ continued to grow in importance and significance among academics and business communities? We illustrate through contingency theory, taking into consideration contingency propositions rather than congruent propositions that a firm's CC could advance due to CSP-CFP relationship but contingent on the MVs and IMs the firms finds itself as summarized in Fig. 1. That is why we take as naive any model that only considers a direct relationship between the variables used in the $\mathrm{BC}$ and call upon the researchers to be cognizant of the possible role of mediating and/or moderating variables (Fig. 2) in their approaches and perspectives in order to clarify further CC literature. This makes the case for a multi-level a pproach to research which is a key weakness of the current research on CC.

Another contribution of this model can be illustrated by the journey from strategic intent to strategy implementation. This is because a firm can have a strategic intent, which takes care of IMs with regard to minimizing risks while maximizing on opportunities within their institutional environment and also a framework, which makes sense in the context of $\mathrm{BC}$ but lacks the MVs to bring it into implementation. For instance, as stated earlier, we realized the importance of intellectual stimulation of the CEO as crucial in implementing CC practices in a way that bring business benefits to the firm and social benefits as well. It is also possible that a firm can have MVs but lacks either BC framework or IMs. In that regard, this study presents CC policy-makers with a panoramic view of $\mathrm{CC}$ drivers, which advance the CC cause in such a fashion that all the stakeholders' interests can be taken into consideration through the interaction of three proposed mechanisms for development in CC.

The final contribution is evident in how the interaction between the three mechanisms has been illustrated with regard to the five $\mathrm{CC}$ dimensions where we propose how $\mathrm{CC}$ can be carried in a holistic fashion by implementing all the five dimensions of CC. Since the five components of $\mathrm{CC}$ require the interaction between three mechanisms to be considered by firm, CC practitioners who explicitly consider this model stands a higher chance of advancing CC cause. In that regard, this study contributes how the interaction between the mechanisms can lead to the implementation of the five $\mathrm{CC}$ dimensions, a recommendation that if followed explicitly by practitioners could lead to holistic implementation of CC. To achieve this goal, the method used is a comprehensive literature review that does a content 
analysis of the existing literature that attempts to explain the mechanisms for development in CC. Finally, this paper gives way for future academic research to explore a multilevel both theoretical and empirical approach for understanding development in Social responsibility as a main business objective, which in turn may have practical implications executing Social Responsibility initiatives in an organizational department, in a firm, in sector and entire macro economy.

\section{Limitations}

As a limitation, fist, we reiterate the taxonomy of the mechanisms for development in CC (BC, MVs and IMs) that forms our multi-level review of the literature review. This triad, a product of retrospection on CC literature has not been empirically validated. However we contend that that the taxonomy should be supported by other theoretical contributions. In that regard, we are encouraged to report that the contribution in our taxonomy is supported by Wood (1991). Moreover, in our opinion, it is not in contradiction to Dahlsrud's (2008) and Garriag and Mele's (2013) contributions.

The interaction between these three levels of mechanisms for $\mathrm{CC}$ develoment (BC, MVs and IMs), but not one acting separately is what could be driving $\mathrm{CC}$ to another level. However, like most overarching theories, it's devoid of parsimony since it could be too complex to apply in an empirical model and also lacking in depth of analysis.

\section{Theoretical implications}

Given that several scholars still populate disciplinary, specialized micro- (social psychology, organizational behavior, and organizational psychology), meso- (business process management and project management) or macro- (strategic management, organizational theory and design, and engineering/systems management) research camps (Hitt et al., 2007; Molloy et al., 2011), the study recommends a multi-disciplinary, multi-level approach to the study in social responsibility.

\section{Abbreviations \\ BC: Business case; CC: Corporate citizenship; CEO: Chief Executive Officer; CFP: Corporate Financial Performance; CSP: Corporate Social Performance; CSR: Corporate Social Responsibility; IMs: Institutional mechanisms; MVs: Managerial values; NGOs: Non-Governmental Organizations}

\footnotetext{
Acknowledgements

First, I want to acknowledge the encouragement I received from my late wife (Rebecca Gombe Mwachongo, the Joy of my son (Matisse Mooij Ogola Onyango) that is the main reason of encouragement to work hard to create an example for him and to my Sister (Josephine Odero Omondi) who took care of the house and my son to enable me work on this publication. Second, we want to thank the two anonymous reviewers for their comments and suggestions, which were fundamental for the final version of this article. We also want to thank the editors for their assistance throughout the review process.
}

\section{Authors' contributions}

This work is derived from ESADE Business School's work toward a PhD in Management Sciences and Innovation. My supervisor who provided a lot of guidance therefore becomes a second author. The author(s) read and approved the final manuscript.

\section{Authors' information}

The first author is the Academic Director- MBA program at Strathmore Business School. He is also the CEO Wanafunzi Investment Unit Trust Fund. $\mathrm{He}$ is a consultant on Strategy Formulation \& Strategy Execution. He sits in Renowned boards as Director and chair of Strategy Execution Committees. He obtained his PhD from ESADE Business School and is a Part-time Professor of IESE Business School and St. Gallen University. He is a director and owner of Halisi Family Hospital and TrailBlazer Business Strategies (TBS). His main research interest is Sustainability Strategies of financial institutions in developing countries.

The second author In the field of research and teaching, has specialized in corporate social responsibility. In particular, he conducts research in two areas:1) CSR of extractive industries in developing areas, particularly in SubSaharan Africa. 2) Values, spirituality and business Education: From the perspective of anthropology, he examines ways to promote, among business leaders and citizens, the values that lead them to contribute to societal welfare through their organizations. He visits Africa on periods of reflection and co-operation. He collaborates with third-sector institutions in Catalonia related with education (regulated and unregulated). He is Professor of Social Analysis and Corporate Social Responsibility. He joined ESADE in September 1998.

\section{Funding}

We appreciate ESADE Business School that sponsored my PhD studies and gave me all the support I needed while working on this review that has been a long period of work.

\section{Availability of data and materials}

The data that support the findings of this review is available from the three online data bases consulted (Google Scholar, Science Direct, ProQuest and Web-cohost) according to the considerations mentioned for the creation of the table. The rest of the data generated or analyzed during this study is included in this published article.

\section{Competing interests}

The authors declare that there is no known competing interest.

Received: 29 May 2020 Accepted: 3 September 2020

Published online: 07 November 2020

\section{References}

Academy, T., \& Review, M. (2017). Reviewed work(s): The transformation of corporate control by Neil Fligstein. Review by: Peter Kreiner. The Academy of Management Review, 16(3), 631-634 Published by: Academy of Management.

Ackerman, R. W. (1973). How companies respond to social demands. Harvard Business Review Retrieved from https://books.google.co.ke/books?id=0c4 ZngEACAAJ.

Aguilera, R. V., \& Jackson, G. (2003). The cross-national diversity of corporate governance: Dimensions and determinants. Academy of Management Review, 28(3), 447-465 https://doi.org/10.5465/AMR.2003.10196772.

Argenti, P. A. (2004). Collaborating with activists: How Starbucks works with NGOs. California Management Review, 47(1), 91-116 https://doi.org/10.2307/ 41166288.

Bahman, S. P., Kamran, N., \& Mostafa, E. (2014). Corporate social responsibility: A literature review. African Journal of Business Management, 8(7), 228-234 https://doi.org/10.5897/ajbm12.106.

Barnett, M. L. (2018). Stakeholder influence capacity and the variability of financial returns to corporate social responsibility. Limits to stakeholder influence: Why the business case won't save the world, 32(3), 56-78.

Baron, D. (2010). Business and its environment, (6th ed., ). Upper Saddle River: Pearson Prentice Hall.

Baron, R. M., \& Kenny, D. A. (1986). The moderator-mediator variable distinction in social psychological research. Conceptual, strategic, and statistical considerations. Journal of Personality and Social Psychology, 51(6), 1173-1182 https://doi.org/10.1037/0022-3514.51.6.1173. 
Bowen, H. R., et al. (2013). Social responsibility of the businessman. lowa: University of lowa Press.

Brealey, R., Myers, S. C., \& Allen, F. (2006). Corporate finance, (8th ed., ). Boston: McGraw-Hill Irwin.

Brodwin, D. R., \& Bourgeois III, L. J. (1984). Strategic implementation: Five approaches to an elusive phenomenon. Strategic Management Journal, 5(3), 241-264.

Brummer, J. (1991). Corporate responsibility and legitimacy, (1st ed., ). New York: Greenwood press.

Burke, L., \& Logsdon, J. M. (1996). How corporate social responsibility pays off. Long Range Planning, 29(4), 495-502 https://doi.org/10.1016/00246301(96)00041-6.

Campbell, J. L. (2007). Why would corporations behave in socially responsible ways? An institutional theory of corporate social responsibility. Academy of Management Review, 32(3), 946-967 https://doi.org/10.5465/AMR.2007. 25275684.

Carroll, A. (1979). A three-dimensional conceptual model of corporate performance. Academy of Management Review, 4, 479-505.

Carroll, A. B., \& Shabana, K. M. (2010). The business case for corporate social responsibility: A review of concepts, research and practice. International Journal of Management Reviews, 12(1), 85-105 https://doi.org/10.1111/j.14682370.2009.00275.x.

Carroll, A. B., \& Shabana, K. M. (2017). The business case for corporate social responsibility: A review of concepts, research and practice, (January 2010). https://doi.org/10.1111/j.1468-2370.2009.00275.x.

Cohen, L. E., Burton, M. D., \& Lounsbury, M. (2016). Introduction: Bringing jobs back in: Toward a new multi-level approach to the study of work and organizations. Research in the Sociology of Organizations, 47, 1-22 https://doi. org/10.1108/S0733-558X20160000047001.

Crane, A., McWilliam, A., Matten, D., Moon, J., \& Seigel, D. S. (2008). The Oxford handbook of corporate social responsibility. Oxoford: Oxford University Press.

Crossman, B., \& Crossman, J. (2011). Conceptualising followership - a review of the literature. Leadership, 7(4), 481-497 https://doi.org/10.1177/ 1742715011416891

Cuddy, A. J. C., Fiske, S. T., \& Glick, P. (2007). The BIAS map: Behaviors from intergroup affect and stereotypes. Journal of Personality and Social Psychology, 92(4), 631-648 https://doi.org/10.1037/0022-3514.92.4.631.

Dahlsrud, A. (2008). How corporate social responsibility is defined: An analysis of 37 definitions. Corporate Social Responsibility and Environmental Management, 15(1), 1-13 https://doi.org/10.1002/csr.132.

Davis-1973-ForAnd Against.pdf. (n.d.).

De Schutter, O. (2008). Corporate social responsibility European style. European Law Journal, 14(2), 203-236 https://doi.org/10.1111/j.1468-0386.2007.00411.x.

Dixit, A. K., \& Pindyck, R. S. (2004). The Options Approach to Capital Investment in Real options and Investments under Uncertainty: Classical Readings and Recent contribution. (E. S. Schwartz and L.Trigeorgis, Ed.). Cambridge: Mass: MIT Press.

Dore, R. (2017). Goodwill and the spirit of market capitalism. Britissh Journal of Sociology, 34(4), 459-482 Published by: Wiley on behalf of The London School of Economics and Political Science. Stable URL: http://www.jstor.org/stable/590932.

Epstein, M. J., \& Roy, M. J. (2001). Sustainability in action: Identifying and measuring the key performance drivers. Long Range Planning. https:/doi.org/ 10.1016/S0024-6301(01)00084-X.

Felin, T., Foss, N. J., \& Ployhart, R. E. (2015). The microfoundations movement in strategy and organization theory. Academy of Management Annals, 9(1), 575632 https://doi.org/10.1080/19416520.2015.1007651.

Fox, T., Ward, \& Howard, B. (2002). Public sector roles in strengthening corporate social responsibility: A baseline study. Washington DC: CSR Practice.

Frank Figge, S. S. (2000). What is "Stakeholder Value"? Developing a Catchphrase Into Benchmarking Too. Paris: University of Luneburge.

Frederick, W. C. 1998. 'Moving to CSR4', Business and Society 37(1), 40-60.

Frederick, W. C. (1987). Theories of corporate social performance. In S. P. Sethi, \& C. Flabe (Eds.), Business and society: Dimensions of conflict and cooperation. New Jersy: Lexington Books.

Fry, L. W., \& Smith, D. A. (1987). Congruence, contingency, and theory building. Academy of Management Review, 12(1), 117-132 https://doi.org/10.5465/amr. 1987.4306496.

Galaskiewwicz, J. (1991). Making corporate actors accountable: Institutionbuilding in Minneapolis. In The new institutionalism in organizational analysis. Chicago: Chicago University Press.
Garriga, E., \& Melé, D. (2013). Corporate social responsibility theories: Mapping the territory. The Journal of Business Ethics, 69-96 https://doi.org/10.1007/978-94007-4126-3_4.

Gerring, J. (2010). Causal mechanisms: Yes, but .... Comparative Political Studies, 43(11), 1499-1526 https://doi.org/10.1177/0010414010376911.

Gray, E. R., \& Balmer, J. M. T. (1998). Managing corporate image and corporate reputation. Long Range Planning, 31(5), 695-702 https://doi.org/10.1016/ S0024-6301(98)00074-0.

Greiner, L. E. (1998). Evolution and revolution as organizations grow. Harvard University Review, 76(3), 695-702.

Guillen, M. (1994). Models of management: Work, authority and organization in comparative perspectives. Chicago: University of Chicago Press.

Haigh, M., \& Jones, M. T. (2006). The drivers of corporate social responsibility: A critical review. Ashridge Faculty Publications, 5(1), 1-9.

Hall, P. A., \& Sosckie, D. W. (2001). Varieties of capitalism: The institutional foundations of comparative advantage. Oxoford: Oxford University Press.

Hartman, C. L., Hofman, P. S., \& Stafford, E. R. (2002). In T. J. N. M. de Bruijn, \& Tukker (Eds.), Environmental collaborations: Potentials and limits. in partnership and leadership. Boston: Kluwere Academic.

Hedberg, B. L. T., Bystrom, P. C., \& Starbuck, W. H. (1976). Camping on seesaws: Prescriptions for a self-designing organization. Administrative Science Quarterly, 21(1), 41 https://doi.org/10.2307/2391877.

Hemingway, C. A., \& Maclagan, P. W. (2004). Managers' personal values as drivers of corporate social responsibility. Journal of Business Ethics, 50(1), 33-44 https://doi.org/10.1023/B:BUSI.0000020964.80208.c9.

Heslin, P. A., \& Ochoa, J. D. (2008). Understanding and developing strategic corporate social responsibility. Organizational Dynamics, 37(2), 125-144 https://doi.org/10.1016/j.orgdyn.2008.02.002.

Hitt, M. A., Beamish, P. W., Jackson, S. E., \& Mathieu, J. E. (2007). Building theoretical and empirical bridges across levels: Multilevel research in management. Academy of Management Journal, 50(6), 1385-1399 https://doi.org/10.5465/AMJ.2007.28166219.

Hitt, M. A., Tyler, B. B., Hardee, C. A., \& Park, D. (1995). Understanding strategic intent in the global marketplace. Academy of Management Perspectives, 9(2), 12-19 https://doi.org/10.5465/ame.1995.9506273265.

Jablonsky, D. (1995). Why is strategy so difficult? Joint Force Quarterly, 10, 6-12.

Kaplan, R. S., \& Norton, D. P. (2006). Transforming the balanced scorecard from performance measurement to stragegic management. M. U. and D. K. Rutterford, Financial strategy (373-391). Chchester: Wiley.

Kesler, G., \& Kates, A. (2015). Bridging Organization Design and Performance. Bridging Organization Design and Performance. https://doi.org/10.1002/ 9781119176299.

Klein, K. J., \& Kozlowski, S. W. J. (1995). Multilevel theory, research, and methods in organizations: Contextual, temporal, and emergent processes. Multilevel theory, research, and methods. In Organizations: Foundations, extensions, and new directions, (pp. 3-50). Wiley.

Latapí Agudelo, M. A., Jóhannsdóttir, L., \& Davídsdóttir, B. (2019). A literature review of the history and evolution of corporate social responsibility. International Journal of Corporate Social Responsibility, 4(1), 1-23 https://doi.org/10.1186/es40991-018-0039-y.

Lee, M. (2008). A review of the theories of corporate social responsibility: Its evolutionary path and the road ahead. International Journal of Management Reviews, 10, 53-73 https://doi.org/10.1111/j.1468-2370.2007.00226.x.

Margolis, J. D., \& Walsh, J. P. (2003). Misery loves companies: Rethinking social initiatives. Administrative Science Quarterly, 48(2), 268-305 Published by: Sage Publications, Inc. on behalf of the Johnson Graduate School of Management. URL: http://www.jstor.org/st.

Mària, J. F., \& Onyango Ogola, F. (2012). Financial institutions' social responsibility in developing countries: A framework of analysis. African Journal of Economic and Management Studies, 3(1) https://doi.org/10.1108/20400701211197311.

Marrewijk, M. (2003). Concepts and definitions of CSR and corporate sustainability: Between agency and communion. Journal of Business Ethics, 44, 95-105 https://doi.org/10.1023/A:1023331212247.

Matten, D., \& Moon, J. (2004). Corporate social responsibility education in Europe. Journal of Business Ethics, 54(4), 323-337 https://doi.org/10.1007/s10551-0041822-0.

Mcguire, J. B., Sundgren, A., \& Schneeweis, T. (1988). Corporate social responsibility and firm financial performance. The Academy of Management Journal, 31(4), 854-872 Published by: The Academy of Management Journal. 
Mcwilliams, A., Siegel, D., \& Wright, P. (2006). Corporate social responsibility: Strategic implications. Journal of Management Studies, 43, 1-18 https://doi. org/10.1111/j.1467-6486.2006.00580.x.

Mirvis, P., \& Googins, B. (2007). Stages of corporate citizenship. Engineering Management Review, IEEE, 34, 145 https://doi.org/10.1109/EMR.2006.261390.

Molloy, J. C., Ployhart, R. E., \& Wright, P. M. (2011). The myth of "the" micro-macro divide: Bridging system-level and disciplinary divides. Journal of Management, 37(2), 581-609 https://doi.org/10.1177/0149206310365000.

Moon, J. (2004). Government as a driver of corporate social responsibility. Research Paper International Center for Corporate Social Responsibility.

MSteger, U. (2006). Building a business case for corporate sustainability., In Managing the business case for sustainability: In S. Schaltegger and M. Wagner (Ed.), The integration of social environmental and economic performance (pp. 412-443). Greenleaf.

Muller, D., Judd, C., \& Yzerbyt, V. (2006). When moderation is mediated and mediation is moderated. Journal of Personality and Social Psychology, 89, 852 $863 \mathrm{https}: / /$ doi.org/10.1037/0022-3514.89.6.852

Murphy, B., Maguiness, P., Pescott, C., Wislang, S., Ma, J., \& Wang, R. (2005). Stakeholder perceptions presage holistic stakeholder relationship marketing performance. European Journal of Marketing, 39, 1049-1059 https://doi.org/ 10.1108/03090560510610716.

North, D. (2004). Institutions, institutional change and economic behavior. Cambridge: Cambriedge University Press.

Nyuur, R. B., Ofori, D. F., \& Debrah, Y. (2014). Corporate social responsibility in subSaharan Africa: Hindering and supporting factors. African Journal of Economic and Management Studies, 5(1), 93-113 https://doi.org/10.1108/AJEMS-012012-0002.

Ogola, F. O., \& Dreer, T. (2012). Market share as an indicator for corporate social responsibility (CSR) spending: The study of Coca Cola's market. African Journal of Business Management, 6(6), 2234-2247 https://doi.org/10.5897/ AJBM11.2133.

Paruchuri, S., Perry-Smith, J. E., Chattopadhyay, P., \& Shaw, J. D. (2018). New ways of seeing: Pitfalls and opportunities in multilevel research. Academy of Management Journal, 61(3), 797-801 https://doi.org/10.5465/amj.2018.4003.

Peccei, R., \& Van De Voorde, K. (2019). The application of the multilevel paradigm in human resource management-outcomes research: Taking stock and going forward. Journal of Management, 45 https://doi.org/10.1177/ 0149206316673720 .

Pivato, S., Misani, N., \& Tencati, A. (2008). The impact of corporate social responsibility on consumer trust: The case of organic food. Business Ethics: A European Review, 17, 3-12 https://doi.org/10.1111/j.1467-8608.2008.00515.x.

Porter, M. E., \& Kramer, M. R. (2006). Strategy \& society: the link between competitive advantage and corporate social responsibility. Harvard Business Review, 84, 78-92.

Preston, L. (1975). Corporation and society: The search for a paradigm. Journal of Economic Literature, 13(2), 434-453.

Pruzan, P. (2001). Corporate reputation: Image and identity. Corporate Reputation Review, 4, 50-64 https://doi.org/10.1057/palgrave.crr.1540132.

Rani, G., \& Hooda, K. (2013). Corporate social responsibility: Review of literature. International Journal of Social Science \& Interdisciplinary Research, 2(6), 38-44.

Rappaport, A. (1998). Creating shareholder value: A guide for managers and investors, (2nd ed., ). New York: Free Press.

Roman, R. M., Hayibor, S., \& Agle, B. R. (1999). The relationship between social and financial performance: Repainting a portrait. Business \& Society, 38(1), 109-125 https://doi.org/10.1177/000765039903800105.

Schaltegger, S., \& Müller, K. (2017). Calculating the true profitability of pollution prevention 1: Environmental accounting for management current practice and future trends, (pp. 86-99) https://doi.org/10.4324/9781351283328-3.

Schaltegger, S. (1998). In accounting for eco-efficiency. In P. and D, B. Nath, L. Hens, \& Compton (Eds.), Environmental Management in Practice, (pp. 272287). London: Rountledge.

Schwaiger, M. (2004). Components and parameters of corporate reputation - An empirical study. Schmalenbach Business Review (Sbr), 56, 46-71 https://doi. org/10.1007/BF03396685.

Siegel, D., Waldman, D., \& Javidan, M. (2006). Components of CEO transformational leadership and corporate social responsibility. Journal of Management Studies, 43, 1703-1725 https://doi.org/10.1111/j.1467-6486.2006.00642.x.

Smith, R. E. (2011). Defining corporate social responsibility: A systems approach for socially responsible capitalism, (pp. 1-80). Penn Libraries: University of Pennsylvania Retrieved from http://repository.upenn.edu/cgi/viewcontent. cgi?article $=1009 \&$ context $=$ od_theses_mp.
Srivastava, A. K., Srivastava, A. A., \& Raibareli, U. P. (2017). Corporate social responsibility (a literature review). https://doi.org/10.13140/RG.2.2.25379.76322.

Steger, U. (2006). Building a business case for corporate sustainability. In S. Schaltegger, \& M. Wagner (Eds.), Managing the business case for sustainability: The integration of social environmental and economic performance, (pp. 412443). Sheffield: Greenleaf.

Suchman, M. (1995). Managing Legitimacy: Strategic and Institutional Approaches. Academy of Management Review, 20, 571-611. The Academy of Management Review, 20, 571 https://doi.org/10.2307/258788.

Thorpe, J., \& Prakash-Mani, K. (2003). Developing value. Greener Management International. https://doi.org/10.9774/GLEAF.3062.2003.wi.00004.

Valor, C. (2005). Corporate social responsibility and corporate citizenship: Towards corporate accountability. Business and Society Review, 110, 191-212 https://doi.org/10.1111/j.0045-3609.2005.00011.x.

Valor, C. (2008). Can consumers buy responsibly? Analysis and solutions for market failures. Journal of Consumer Policy, 31, 315-326 https://doi.org/10. 1007/s10603-008-9070-9.

Visser, W. (2005). Corporate citizenship in South Africa. Journal of Corporate Citizenship, 2005 https://doi.org/10.9774/GLEAF.4700.2005.su.00007.

Vogel, D. (1992). The globalization of business ethics: Why America remains distinctive. California Management Review, 35(1), 30-49 https://doi.org/10. 2307/41166711.

Waddell, S. (2000). New institutions for the practice of corporate citizenship: Historical. intersectoral. Business and Society Review, 105(1), 107.

Wagner, M., Nguyen-Van, P., Azomahou, T., \& Wehrmeyer, W. (2002). The relationship between the environmental and economic performance of firms. An empirical analysis of the European paper industry. Corporate Social Responsibility and Environmental Management, 9, 133-146 https://doi.org/10. 1002/csr.22.

Wagner, M., \& Schaltegger, S. (2004). The effect of corporate environmental strategy choice and environmental performance on competitiveness and economic performance: An empirical study of EU manufacturing. European Management Journal, 22, 557-572 https://doi.org/10.1016/j.emj.2004.09.013.

Waldman, D. A. (1999). CEO Charismatic Leadership: Levels-of-Management and Levels-of-Analysis Effects Author(s): David A. Waldman and Francis J. Yammarino Source: The Academy of Management Review, 24(2), 266-285. Published by: Academy of Management Stable. https://www.jstor.org/ stable/259082.

Wartick, S. L., \& Rude, R. E. (1986). Issues management: Corporate fad or corporate function? California Management Review, 29(1), 124-140 https://doi.org/10. 2307/41165231.

Weber, M. (2008). The business case for corporate social responsibility: A companylevel measurement approach for CSR, (pp. 247-261) https://doi.org/10.1016/j. emj.2008.01.006.

Whitley, R. (2004). In F. Dobbin (Ed.), The social construction of organizations and markets: The comparative analysis of business recipes. Princeton: Princeton University Press.

Wiedmann, K. P., \& Buxel, H. (2005). Corporate reputation management in Germany: Results of an empirical study. Corporate Reputation Review, 8(2), 145-163 https://doi.org/10.1057/palgrave.crr.1540246.

Williamson, D., Lynch-Wood, G., \& Ramsay, J. (2006). Drivers of environmental behaviour in manufacturing SMEs and the implications for CSR. Journal of Business Ethics, 67, 317-330 https://doi.org/10.1007/s10551-006-9187-1.

Wood, D. (1991). Social issues in management: Theory and research in corporate social performance. Journal of Management, 17, 383-406 https://doi.org/10. 1177/014920639101700206.

\section{Publisher's Note}

Springer Nature remains neutral with regard to jurisdictional claims in published maps and institutional affiliations. 